\title{
Effect of sodium bisulphate on the stability of octreotide acetate: compatibility study with dexamethasone injection
}

\author{
Kouichi Tanabe $^{1)}$, Jun Ohkubo ${ }^{1)}$, Tomoaki Ikezaki ${ }^{1)}$, Shohei Kitayama ${ }^{2)}$, \\ Yuki Tsuneda ${ }^{2)}$, Atsumi Nitta ${ }^{3)}$, Lisa Imamura ${ }^{2)}$, Hideto $\mathrm{To}^{2)}$, \\ Masanari Shimada ${ }^{4)}$, Nozomu Murakami ${ }^{4)}$ and Hidenori Kitazawa ${ }^{1)}$
}

\begin{abstract}
1) Department of Pharmacy, Saiseikai Takaoka Hospital, 2) Department of Medical Pharmaceutics, Faculty of Pharmaceutical Sciences, Graduate School of Medicine and Pharmaceutical Sciences, University of Toyama, 3) Department of Pharmaceutical Therapy and Neuropharmacology, Faculty of Pharmaceutical Sciences, Graduate School of Medicine and Pharmaceutical Sciences, University of Toyama, 4) Department of Surgery, Saiseikai Takaoka Hospital
\end{abstract}

Recived 10/23/2012, revised 11/12/2012, accepted 12/25/2012

\begin{abstract}
Background: Although several dexamethasone phosphate preparations are commercially available and frequently administered with octreotide acetate, their compatibility remains unknown. Aim: We investigated the effect of $\mathrm{pH}$ and sodium bisulphate on the stability of octreotide acetate. Measurement design: Octreotide acetate percentage was measured 3 and 10 days after it was mixed with 2 dexamethasone phosphate preparations containing different concentrations of sodium bisulphate as an additive, and in one that did not contain sodium bisulphate. Solutions were also analysed after they were prepared using phosphate buffer to achieve $\mathrm{pH}$ values of 4.0, 7.0, and 9.0. The initial octreotide acetate concentration was $41.7 \mathrm{~g} / \mathrm{mL}$. High-performance liquid chromatography was used for measurement. Results: The octreotide acetate percentage in the mixture with dexamethasone phosphate without sodium bisulphate was maintained at $\geq 95 \%$ for up to 10 days. However, mixing octreotide acetate with the other 2 agents resulted in a significant decrease to $85 \%$. The octreotide acetate percentage was $<90 \%$ after sodium bisulphate-containing solution was stored at room temperature under light-protected conditions for 3 days. The percentage of octreotide acetate in the $\mathrm{pH} 7.0$ solution was $<90 \%$ three days after preparation; however, in the $\mathrm{pH} 4.0$ solution, it was maintained at $\geq 95 \%$ for up to 10 days. Conclusions: Our results suggest that octreotide acetate is hydrolysed in the presence of sodium bisulphate, leading to a decrease in the percentage of octreotide acetate in the solution, which can be avoided using sodium bisulphate-free dexamethasone phosphate preparations.
\end{abstract}

Palliat Care Res 2013; 8(2): 177-83

Key words: octreotide, dexamethasone, sodium bisulphate, compatibility, $\mathrm{pH}$

\section{Introduction}

Octreotide acetate (OCT) is a cyclic octapeptide containing a disulphide bond that is necessary for the physiological activities of the molecule (Fig. 1) ${ }^{1-3}$. It is a key drug for cancerous, peritonitis-related obstruction of the digestive tract ${ }^{4,5)}$. In terminal cancer patients with obstruction of the digestive tract, early combination therapy with OCT and dexamethasone sodium phosphate (DEX) reduces oedema of the digestive tract, decreasing digestive tract pressure and relieving obstruction $^{6}$. These 2 agents are frequently administered together for palliative care.

Sodium bisulphate (SBS) is an additive contained in some DEX injection preparations and has been reported to inactivate physiologically active peptides through peptide hydrolysis or disulphide bond cleavage ${ }^{7,8}$. However, this change cannot be evaluated visually. In addition, no study has examined the compatibility of OCT with DEX injection in the absence of SBS. Whether DEX preparations contain SBS differs between countries. In Japan, SBS-containing and SBS-free DEX preparations are both commercially available.

It has been reported that continuous subcutaneous administration of OCT and other drugs in a mixture is useful for the patients who cannot take the drugs orally ${ }^{9}$. Currently, limited information is available regarding the stability of OCT mixed with other drugs including DEX injection preparations, excluding diamorphine hydrochloride ${ }^{10)}$; this information is necessary for estimating compatibility. In combination therapy with OCT and DEX, recommendations specify that DEX should be subcutaneously administered separately from $\mathrm{OCT}^{11)}$. However, given that frequent punctures reduce quality of life (QOL), identifying the causes of incompatibility and investigating methods that may allow them to be injected as a mixture may be beneficial to 


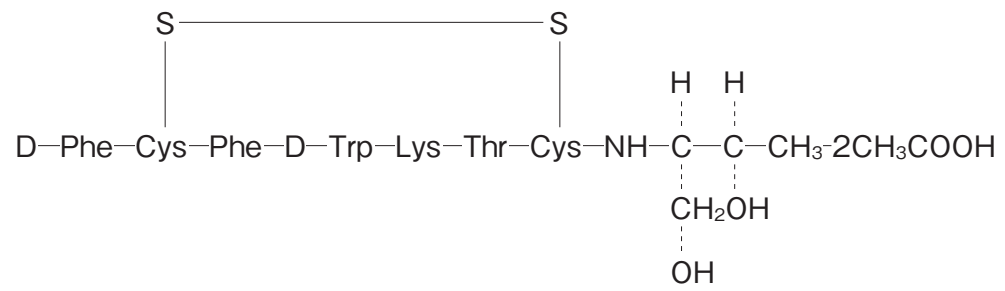

Fig. 1 Structure and amino acid sequence of octreotide

patients. In this study, both SBS-containing and SBS-free DEX injection preparations were mixed with OCT, and the concentration of OCT was quantified using high-performance liquid chromatography (HPLC) to evaluate the effect of SBS on the stability of OCT mixed with DEX injection preparations. The effect of $\mathrm{pH}$ on the stability of the mixtures was also investigated because of an important factor influencing a hydrolysis reaction ${ }^{12}$.

\section{Methods}

\section{Materials}

OCT was obtained from Sigma-Aldrich Japan (Japan). Sand$\operatorname{ostatin}^{\circledR}$ for subcutaneous (S.C.) injection $(100 \mu \mathrm{g} / \mathrm{mL})$ was purchased from Novartis Pharma Co., Ltd. (Japan). For the evaluation of DEX products with different SBS concentrations, Dexart ${ }^{\circledR}$ injection (SBS $2 \mathrm{mg} / \mathrm{mL}$; DEX-SBS 2.0), Decadron ${ }^{\circledR}$ injection (SBS $0.5 \mathrm{mg} /$ $\mathrm{mL}$; DEX-SBS 0.5), and Orgadrone ${ }^{\circledR}$ injection (SBS-free; DEX-SBS 0) solutions were purchased from Fuji Pharma Co. Ltd. (Japan), MSD Co. Ltd. (Japan), and Daiichi-Sankyo Co. Ltd. (Japan), respectively. All of the other chemicals used were reagent grade and commercially available.

\section{OCT preparations}

To determine the experimental conditions, the daily doses of OCT and DEX were assumed to be $300 \mu \mathrm{g}$ and $4.0 \mathrm{mg}$, respectively. Based on continuous S.C. administration for 7 days at a flow velocity of 0.3 $\mathrm{mL} / \mathrm{h}^{13)}$, the final concentrations of OCT and DEX were established as $41.7 \mu \mathrm{g} / \mathrm{mL}$ and $0.556 \mathrm{mg} / \mathrm{mL}$, respectively.

1. Compatibility study with commercially available preparations

OCT was mixed with 3 DEX preparations (DEX-SBS 2.0, DEX-SBS 0.5, and DEX-SBS 0) and diluted with physiological saline to achieve concentrations of OCT and DEX that were $41.7 \mu \mathrm{g} / \mathrm{mL}$ and $0.556 \mathrm{mg} / \mathrm{mL}$, respectively. In these preparations, the final SBS concentrations in the mixed samples containing DEX-SBS 2.0, DEX-SBS 0.5 , and DEX-SBS 0 were $0.278,0.0694$, and $0 \mathrm{mg} / \mathrm{mL}$, respectively. For consistency with conditions used in clinical practice, $\mathrm{pH}$ was not adjusted. Each sample was stored in a $1.5 \mathrm{~mL}$ microtube (Promega, Tokyo, Japan) under light-protected conditions, and the percentage of OCT in the sample was measured after 3 and 10 days.

\section{Effect of $\mathrm{pH}$}

Each sample was diluted to an OCT concentration of $41.7 \mu \mathrm{g} / \mathrm{mL}$ with phosphate buffer at $\mathrm{pH}$ values of 4.0, 7.0, and 9.0. The $\mathrm{pH}$ was adjusted with sodium dihydrogen phosphate solution and disodium hydrogen phosphate. Each sample was stored in a $1.5 \mathrm{~mL}$ microtube (Promega) at room temperature under light-protected conditions, and the percentage of OCT in the sample was measured after 3 and 10 days

\section{Effect of SBS}

To exclude the effect of $\mathrm{pH}$, a solution containing $45 \mathrm{mg}$ D-mannitol and $3.4 \mathrm{mg} / \mathrm{mL}$ lactic acid was mixed with saturated sodium hydrogen carbonate solution so that the $\mathrm{pH}$ value was 4.2 (OCT vehicle); this solution was used to dilute OCT. The composition of the OCT vehicle was similar to that of Sandostatin ${ }^{\circledR}$ excluding OCT. We investigated the stability of OCT when SBS-free control and SBS-containing (concentration of SBS: $0.3 \mathrm{mg} / \mathrm{mL}$ ) samples were stored at room temperature or in a cool place $\left(4^{\circ} \mathrm{C}\right)$. In these samples, the concentration of OCT was $41.7 \mu \mathrm{g} / \mathrm{mL}$. Each sample was stored in a $1.5-\mathrm{mL}$ microtube (Promega) under light-protected conditions, and the percentage of OCT in the sample was measured after 3 and 10 days.

\section{HPLC analysis}

For HPLC analysis ${ }^{14}$, we used an LC-2010CHT HPLC system (Shimadzu Corporation, Kyoto, Japan) and LC Solution analytical software (Shimadzu Corporation). The injection volume was $10 \mu \mathrm{L}$ and the measurement wavelength was $210 \mathrm{~nm}$. Measurement was performed using a COSMOSIL5C18-MS- II reverse-phase column (column diameter: $4.6 \mathrm{~mm}$; column length: $150 \mathrm{~mm}$ ) (Nacalai Tesque Co., Ltd., Kyoto, Japan) at room temperature. Mobile phases A (water: acetonitrile: $1 \mathrm{M}$ tetramethylammonium hydroxide solution= 440: 50: 10) and B (water:acetonitrile: $1 \mathrm{M}$ tetramethylammonium hydroxide solution $=190: 300: 10$ ) were prepared. The $\mathrm{pH}$ was adjusted to 4.5 using phosphate solution. We used a gradient system in which the A-to-B ratio was linearly changed from $73: 27$ to $55: 45$ in $12 \mathrm{~min}$ after the start of analysis. Measurement was performed each three times, and data were shown as the means \pm S.D. $(n=3)$.

\section{Assay line}

OCT was diluted with the OCT vehicle for the preparation of a specific volume of standard solutions (OCT concentrations: 1, 5, 10, 20 , and $50 \mu \mathrm{g} / \mathrm{mL})$. Each standard solution $(10 \mu \mathrm{L})$ was infused into the HPLC system, and an assay line was prepared using the peak heights ( $\mathrm{x}$ ) and concentrations (y).

\section{Statistical analysis}

Statistical comparisons were made using one-way ANOVA followed by Tukey's test. P values of $<0.05$ were considered to indicate significance. OCT stability was defined as the maintenance of at least 
Table 1 Changes in the percentage of OCT after mixing with DEX

\begin{tabular}{|c|c|c|c|c|}
\hline \multirow[b]{2}{*}{ Mixed drug } & \multicolumn{3}{|c|}{ The percentage of OCT } & \multirow{2}{*}{$\begin{array}{c}\text { The final SBS } \\
\text { concentration } \\
(\mu \mathrm{g} / \mathrm{mL})\end{array}$} \\
\hline & Day 0 & Day 3 & Day 10 & \\
\hline DEX-SBS 0 & $100 \pm 7.9$ & $98.9 \pm 2.4$ & $96.7 \pm 0.2$ & 0 \\
\hline DEX-SBS 0.5 & $100 \pm 3.0$ & $93.8 \pm 3.6$ & $85.1 \pm 2.0^{*}$ & 0.069 \\
\hline DEX-SBS 2.0 & $100 \pm 2.2$ & $89.9 \pm 2.0^{*}$ & $85.4 \pm 1.6^{*}$ & 0.28 \\
\hline
\end{tabular}

Data were shown as the means \pm S.D. $(n=3)$.

$* p<0.001$ (versus the initial concentration).

OCT: octreotide acetate, DEX: dexamethasone sodium phosphate, SBS: sodium bisulphate

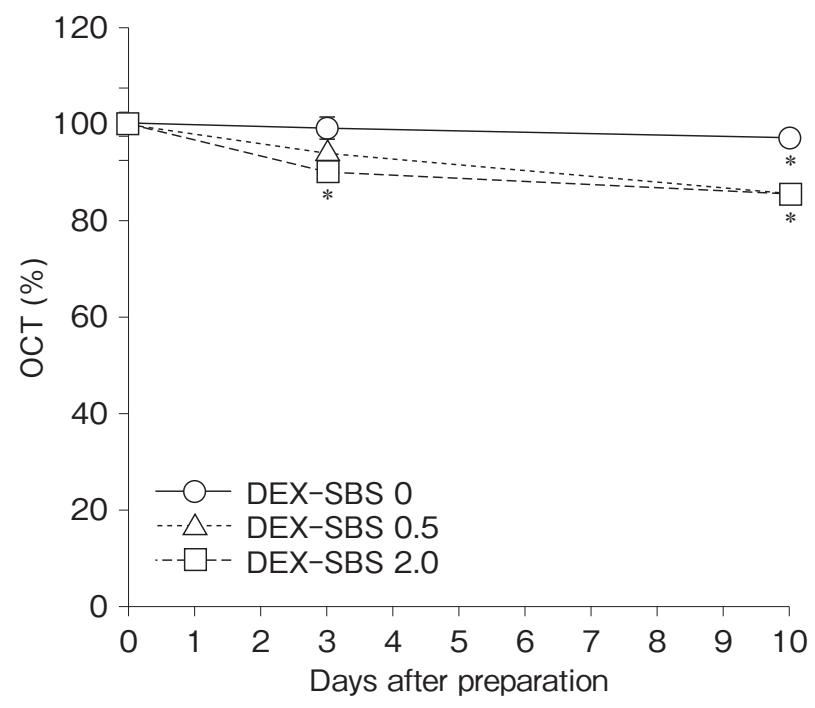

Fig. 2 Serial compositional changes in octreotide acetate (OCT) and dexamethasone sodium phosphate (DEX) preparations

${ }^{*} p<0.001$ (versus the initial concentration)

The percentage of OCT in the sample was $95 \%$ or more until 10 days after its preparation only when it was mixed with sodium bisulphate (SBS)-free Orgadrone ${ }^{\circledR}$ (DEX-SBS 0) injection solution.

$90 \%$ of the initial OCT concentration ${ }^{14)}$.

\section{Results}

1 Compatibility study with commercially available preparations

The assay lines showed linearity at 1 to $50 \mu \mathrm{g} / \mathrm{mL}$. When OCT was mixed with DEX-SBS 0, the percentage of OCT in the sample was $95 \%$ or greater for 10 days after its preparation $(96.7 \% \pm 0.2 \%)$. When OCT was mixed with DEX-SBS 0.5, the percentage of OCT in the sample was $90 \%$ or greater 3 days after its preparation $(93.8 \%$ $\pm 3.6 \%$ ). However, the percentage significantly decreased to $85.1 \%$ $\pm 2.0 \%$ after 10 days $(p<0.001)$. When OCT was mixed with DEX-SBS 2.0, the percentage of OCT in the sample was less than $90 \%$ three days after its preparation $(89.9 \% \pm 2.0 \%)$, which showed a significant decrease $(p<0.001)$ (Table 1, Fig. 2). The $\mathrm{pH}$ values after preparation ranged from 5.0 to 7.0 .

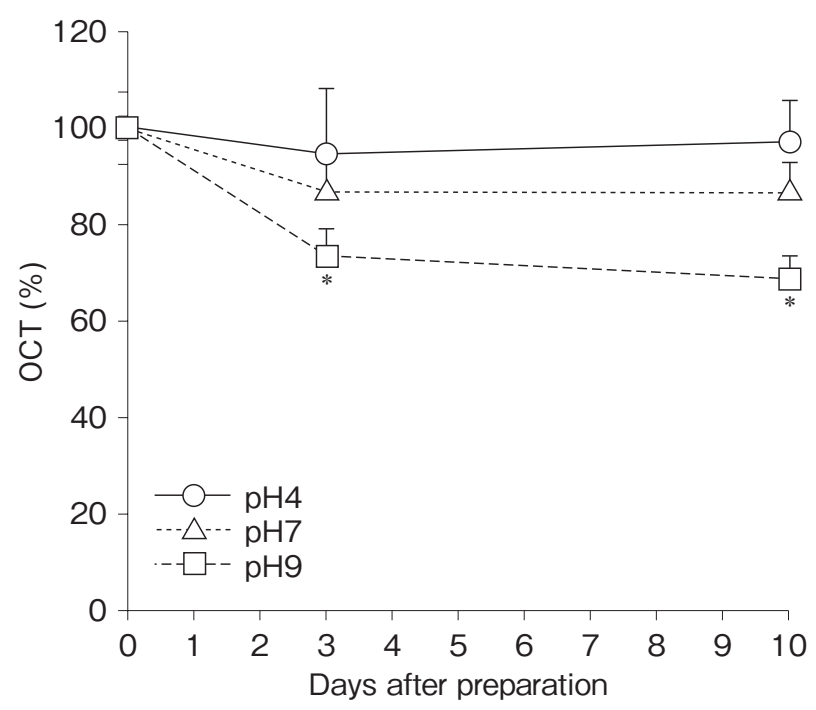

Fig. 3 Serial changes in the percentage of OCT in the sample with respect to $\mathrm{pH}$ values

$* p<0.001$ (versus the initial concentration)

At a $\mathrm{pH}$ value of 4.0, the percentage of OCT in the sample was most stable.

\section{Effect of $\mathrm{pH}$}

At a $\mathrm{pH}$ value of 4.0, the percentage of OCT in the sample was $95 \%$ or more until 10 days after its preparation $(97.7 \% \pm 7.7 \%)$, whereas at a $\mathrm{pH}$ value of 7.0, the percentage of OCT was less than $90 \%$ after 3 days ( $87.6 \% \pm 8.7 \%$ ); however, no significant difference was found. At a pH value of 9.0, a significant decrease in the percentage of OCT in the sample was observed 3 days after its preparation $(73.9 \% \pm 5.6 \%$ ), which was reduced to $68.7 \% \pm 4.9 \%$ after 10 days (Fig. 3).

\section{Effect of SBS}

When SBS-containing OCT solution was stored at room temperature, the percentage of OCT in the sample significantly decreased to less than $90 \%$ three days after its preparation $(84.4 \% \pm 4.0 \%, p<$ 0.001 , versus the initial concentration). When the solution was stored in a cool place, the percentage of OCT was $90 \%$ or more after 3 days $(93.1 \% \pm 2.5 \%)$, but significantly decreased to $78.2 \% \pm 1.5 \%$ after 10 days ( $p<0.001$, versus the initial concentration) (Fig. 4).

Furthermore, the retention time of OCT was $5.4 \mathrm{~min}$. After 10 days 


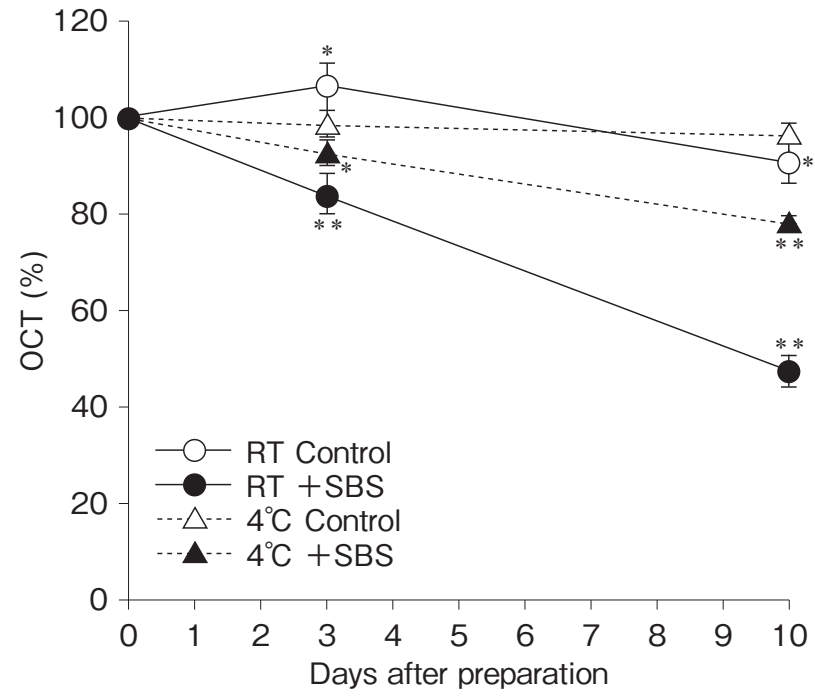

Fig. 4 Effect of sodium bisulphate (SBS) on the percentage of OCT in the sample

${ }^{*} p<0.05,{ }^{*} p<0.001$ (versus the initial concentration)

When SBS-containing OCT solution was stored at room temperature (RT) or in a cool place, the percentage of OCT in the sample significantly decreased to less than $90 \%$ after 3 or 10 days.

of storage at room temperature in the presence of SBS, chromatograms showed new peaks other than the one corresponding to OCT (Fig. 5).

\section{Discussion}

This is the first study to elucidate the effect of SBS on the stability of OCT, with results revealing that compositional changes in OCT can be avoided by selecting SBS-free DEX preparations. No decrease in the percentage of OCT in the sample was observed for 10 days only when OCT was mixed with an SBS-free DEX preparation. In addition, $\mathrm{pH}$ was maintained at less than 7.0 for all of the mixed solutions, suggesting that SBS is an important factor influencing the percentage of OCT in a sample mixed with DEX. Moreover, the experiment in which the effect on OCT was investigated in the presence or absence of SBS also showed that the percentage of OCT in the sample serially decreased only in the presence of SBS, further supporting its involvement.

Several studies have shown that OCT stored in polypropylene syringes in a cool place $\left(3^{\circ} \mathrm{C}\right)$ under light-protected conditions was stable for approximately 1 month $^{14,15)}$. However, in the presence of SBS, it was impossible to prevent a decrease in the percentage of OCT in the sample at a $\mathrm{pH}$ value of 4.0 , which is the $\mathrm{pH}$ at which OCT may be the most stable based on the results of our experiments investigating the effect of $\mathrm{pH}$, even when the sample was stored in a cool place under light-protected conditions.

The SBS-related decrease in the percentage of OCT may be associated with disulphide-bond cleavage and peptide hydrolysis. However, according to studies with insulin ${ }^{8,16)}$, the cleavage reactions of disulphide bonds with SBS proceed in the absence of denaturizing agents when interpeptide-chain bonds are detected. However, intra-chain di-
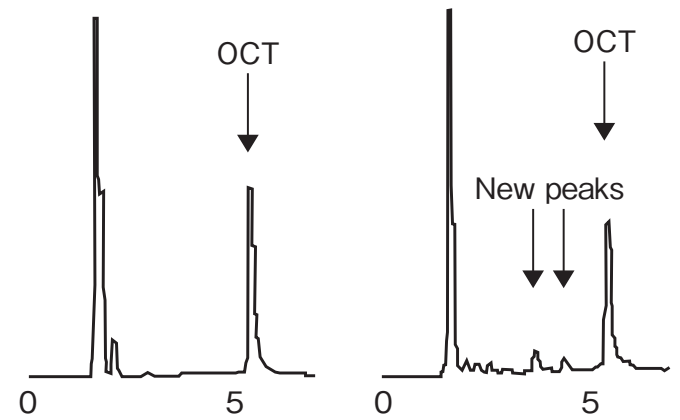

A: In the absence of SBS B. In the presence of SBS

Fig. 5 Chromatogram of OCT at a concentration of $41.7 \mu \mathrm{g} / \mathrm{mL}$ stored at room temperature for 10 days

SBS: sodium bisulphate

sulphide bonds, as they are found in OCT, have a cyclic structure. Therefore, such reactions do not proceed in the absence of denaturizing agents. In addition, chromatograms showed several new peaks, suggesting that SBS promoted the hydrolysis of OCT, not the cleavage reactions of disulphide bonds as the insulin study. Thus, when mixing OCT with DEX preparations, an SBS-free DEX formulation should be used.

In conclusion, SBS-free DEX preparations should be selected when mixing OCT with DEX is necessary. In addition, when OCT is mixed with agents other than DEX preparations, whether the formula is suitable with respect to $\mathrm{pH}$ changes and the presence or absence of SBS should be evaluated. In some countries where SBS-free DEX preparations are available, OCT and DEX preparations may be administered as a mixture. Such measures that enable the administration of OCT and DEX as a mixture will decrease the frequency of punctures, which may reduce pain in patients who undergo combination therapy with these drugs. This study provides new information on the possible mechanisms involved in the compatibility of OCT with DEX preparations, and identifies a stable, mixed administration method for OCT and DEX preparations.

\section{References}

1) Pless J, Bauer W, Briner U, et al. Chemistry and pharmacology of SMS 201-995, a long-acting octapeptide analogue of somatostatin. Scand J Gastroenterol 1986; 21 (Suppl 119): 54-64.

2) Pless J. From somatostatin to Sandostatin: history and chemistry. Metabolism 1992; 41 (Suppl 2): 5-6.

3) Pless J. The history of somatostatin analogs. J Endocrinol Invest 2005; 28 (Suppl): 1-4.

4) Ripamonti C, Mercadante S. Pathophysiology and management of malignant bowel obstruction. In Hanks G, Cherny NI, Christakis NA, et al (eds). Oxford Textbook of Palliative Medicine, 4th ed. Oxford University Press, New York, 2010; 850-63.

5) Ripamonti C, Twycross R, Baines M, et al. Clinical-practice recommendations for the management of bowel obstruction in patients with end-stage cancer. Support Care Cancer 2001; 9: 223-33.

6) Mercadante S, Ferrera P, Villari P, et al. Aggressive pharmacological 
treatment for reversing malignant bowel obstruction. J Pain Symptom Manage 2004; 28: 412-6.

7) Cecil R, Loening UE. The reaction of the disulphide groups of insulin with sodium sulphite. Biochem J 1960; 76: 146-55.

8) Cecil R, Wake RG. The reactions of inter- and intra-chain disulphide bonds in proteins with sulphite. Biochem J 1962; 82: 401-6.

9) Mercadante S. Tolerability of continuous subcutaneous octreotide used in combination with other drugs. J Palliat Care 1995; 11: 14-6.

10) Fielding H, Kyaterekera N, Skellem GG, et al. The compatibility and stability of octreotide acetate in the presence of diamorphine hydrochloride in polypropylene syringes. Palliat Med 2000; 14 : 205-7.

11) Twycross R, Wilcock A. Compatibility charts. In Twyoross R, Wilcock A (eds). Palliative Care Formulary, 3rd ed. Palliativedrugs.com Ltd., Nottingham, 2007; 583-97.
12) Horioka M. Principles and Practice of Dispensing Pharmacy, 2nd ed. Nanzando co. Ltd., Tokyo, 1995; 323-8. (in Japanese)

13) Tanabe K, Ikezaki T, Ohkubo J, et al. Efficacy criteria of octreotide in abdominal symptoms for home palliative care. Jpn J Pharm Palliat Care Sci 2010; 3: 53-61. (in Japanese)

14) Stiles ML, Allen LV Jr, Resztak KE, et al. Stability of octreotide acetate in polypropylene syringes. Am J Hosp Pharm 1993; 50: 2356-8.

15) Ripley RG, Ritchie DJ, Holstad SG. Stability of octreotide acetate in polypropylene syringes at 5 and -20 dogress C. Am J Health Syst Pharm 1995; 52: 1910-1.

16) Blundell TL, Dodson GG, Dodson E, et al. X-ray analysis and the structure of insulin. Recent Prog Horm Res 1971; 27: 1-40.

Potential conflicts of interest; The author(s) indicated no potential conflicts interest. 


\section{原蓶}

\section{オクトレオチド酢酸塩の安定性に対する亜硫酸水素 ナトリウムの影響—デキサメタゾン注射剤との配合変化試験}

田辺 公一 ${ }^{1)}$, 大久保 純 $^{1)}$, 池㟝 友明 ${ }^{1)}$, 北山 祥平 ${ }^{2)}$, 恒田 祐樹 ${ }^{2)}$, 新田 淳美 ${ }^{3)}$, 今村 理佐 ${ }^{2}$, 藤 秀人 ${ }^{2)}$, 島田 雅也 ${ }^{4)}$, 村上 望 ${ }^{4}$, 北澤 英徳 ${ }^{1)}$

1) 富山県済生会高岡病院 薬剤部, 2) 富山大学大学院医学薬学研究部 (薬学) 医療薬学研究室,

3) 富山大学大学院医学薬学研究部 (薬学) 薬物治療学研究室, 4) 富山県済生会高岡病院 外科

【背景】オクトレオチド酢酸塩（以下, OCT）と併用頻度の高いデキサメタゾンリン酸塩（以下, DEX）製剂との配合変 化の機序については不明な点が多い.【目的】本研究では $\mathrm{pH}$ および添加物である亜硫酸水素ナトリウム（以下, SBS）に着 目しOCT の安定性を検討した.【測定方法】SBS 濃度の異なる市販の DEX との混合溶液, およびリン酸緩衝液で $\mathrm{pH} 4,7$ および 9 に調製した溶液, 並びに SBS 添加溶液の OCT 残存率を調製後 3 および 10 日後にそれぞれ HPLC (高速液体ク ロマトグラフィー) を用いて測定した.【結果】SBS を含まない DEX との配合において混合後 10 日目まで OCT残存率は 95\%以上に維持されたが, 他剂ではいずれも 85\%に有意に低下した. また, SBS との配合では 3 日で $90 \%$ 未満へと OCT 残存率の有意な低下が認められた.【考察・結論】OCT USBS 共存下で加水分解により残存率が低下することが示唆され, SBS を含まないDEX 製剂を用いることでこの配合变化を避けうることが明らかとなった.

Palliat Care Res 2013; 8(2): 177-83

Key words: オクトレオチド, デキサメタゾン, 亜硫酸水素ナトリウム, 配合変化, pH

表 1 DEX 製剂混合後の OCT 残存率

\begin{tabular}{c|c|c|c|c}
\hline $\begin{array}{c}\text { 混合した } \\
\text { DEX 製剤 }\end{array}$ & \multicolumn{3}{|c|}{ OCT 残存率 } & \multirow{2}{*}{$\begin{array}{c}\text { 最終 SBS 濃度 } \\
(\mu \mathrm{g} / \mathrm{mL})\end{array}$} \\
\cline { 2 - 4 } DEX-SBS 0 & $100 \pm 7.9$ & $98.9 \pm 2.4$ & $96.7 \pm 0.2$ & 0 \\
\hline DEX-SBS 0.5 & $100 \pm 3.0$ & $93.8 \pm 3.6$ & $85.1 \pm 2.0^{*}$ & 0.069 \\
\hline DEX-SBS 2.0 & $100 \pm 2.2$ & $89.9 \pm 2.0^{*}$ & $85.4 \pm 1.6^{*}$ & 0.28 \\
\hline
\end{tabular}

結果は mean $\pm S D$ で示した $(n=3)$.

${ }^{*} p<0.001$ (versus the initial concentration).

OCT: octreotide acetate, DEX: dexamethasone sodium phosphate, SBS: sodium bisulphate

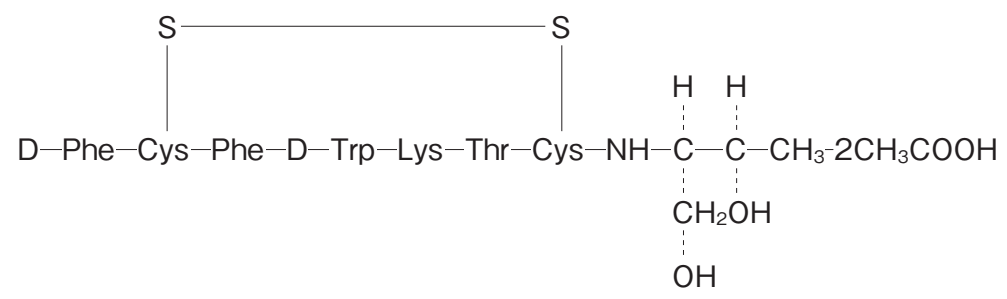

図 1 OCT のアミノ酸配列および構造 


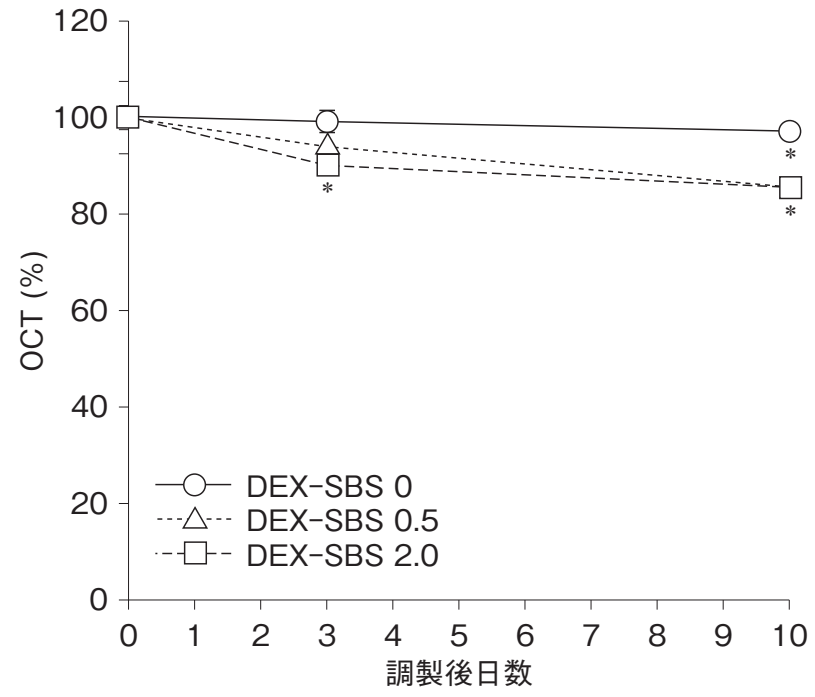

図 2 OCT と DEX 製剂との経時的配合変化 $* p<0.001$ (versus the initial concentration) 試料中の OCT 残存率は SBS を含まない DEX 製剂である オルガドロン注 (DEX-SBS 0) と混合した時のみ, 調製後 10 日間まで $95 \%$ 以上を維持した。

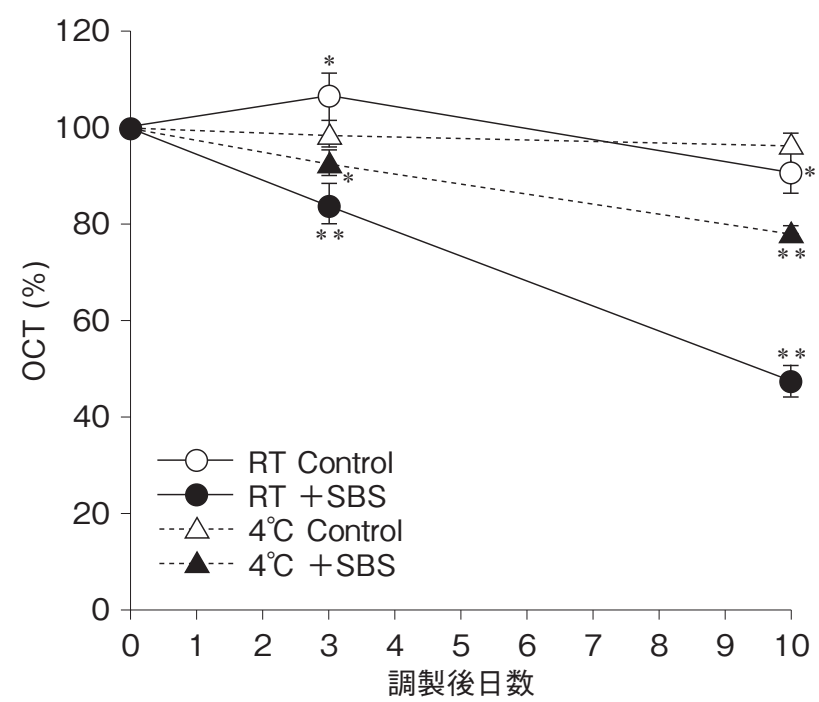

図 4 OCT 残存率に対する SBS の影響

${ }^{*} p<0.05,{ }^{*} p<0.001$ (versus the initial concentration) SBS を含む溶液の OCT 残存率は, 室温保存時 (RT) は 3 日 後に, 冷所保存時 $\left(4^{\circ} \mathrm{C}\right)$ は 10 日後に $90 \%$ 未満に有意に減少 した.

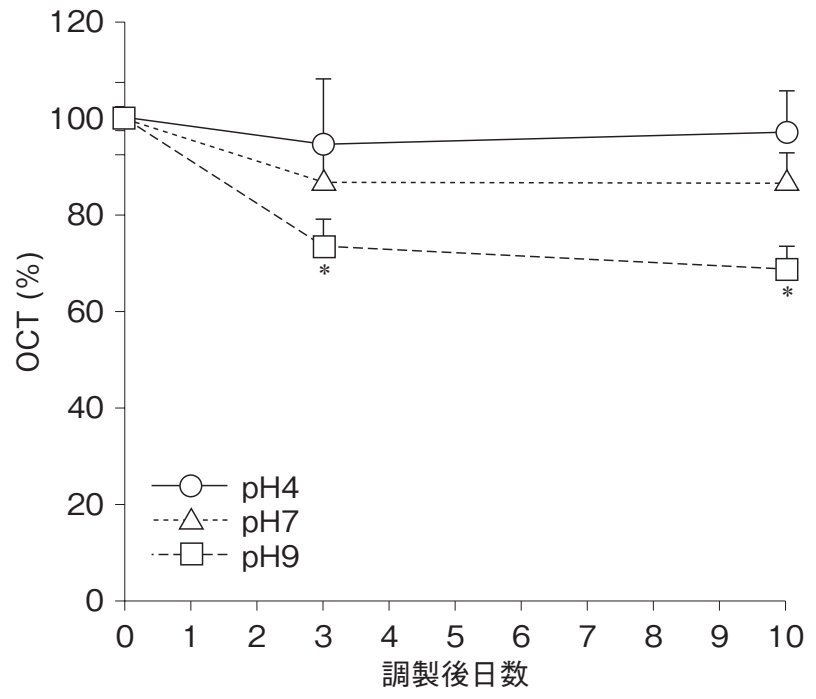

図 $3 \mathrm{pH}$ 別 OCT 残存率の経時的变化 ${ }^{*} p<0.001$ (versus the initial concentration) OCT は pH 4.0 において最も安定であった。

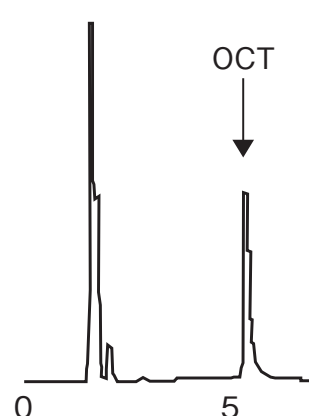

A: SBSなし

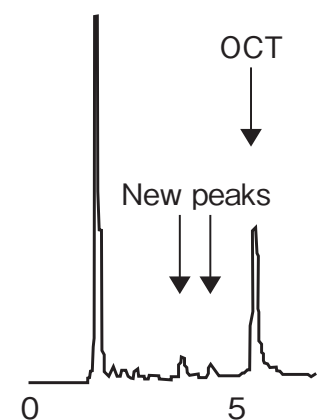

B: SBS 添加
図 5 OCT $41.7 \mu \mathrm{g} / \mathrm{mL}$ 室温 10 日間保存後の クロマトグラム 